\title{
Pliocene flora from S. Pedro da Torre deposits (Minho, NW Portugal)
}

\section{Manuel VIEIRA \\ Emília POÇAS}

Centro de Geologia da Universidade do Porto, Universidade do Minho,

Campus de Gualtar, 4710-057 Braga (Portugal)

manuelvieira@dct.uminho.pt

João PAIS

CICEGe, Departamento de Ciências da Terra, Faculdade de Ciências e Tecnologia, Universidade Nova de Lisboa, 2829-516 Caparica (Portugal)

Diamantino PEREIRA

Centro de Geologia da Universidade do Porto, Universidade do Minho, Campus de Gualtar, 4710-057 Braga (Portugal)

Vieira M., Poças E., Pais J. \& Pereira D. 2011. - Pliocene flora from S. Pedro da Torre deposits (Minho, NW Portugal). Geodiversitas 33 (1): 71-85. DOI: 10.5252/g2011n1a5.

KEY WORDS

Pliocene, palynology, vegetation, palaeoenvironment, Minho Basin, NW Portugal.

MOTS CLÉS Pliocène, palynologie, végétation, paléoenvironnement, bassin du Minho,

\section{ABSTRACT}

This paper deals with the systematic and botanical description of the microfloral elements from the Pliocene S. Pedro da Torre section (NW Portugal) and the description of the palaeoenvironment and palaeoclimate, for use as a correlation attempt with other Pliocene deposits. The S. Pedro da Torre section represents one of the main sites which may help us to understand the vegetation and the paleoenvironment of the Pliocene north-western Iberian Peninsula. Nearly 70 different taxa were indentified (including bryophytes, ferns, gymnosperms and angiosperms), which indicate a palaeowetland setting, dominated by arboreal vegetation that developed under humid and warm climatic conditions.

\section{RÉSUMÉ}

Flore pliocène des dépôts de S. Pedro Da Torre (Minho, NW Portugal).

Ce travail concerne la description botanique et systématique d'éléments microfloraux du Pliocène de S. Pedro da Torre (NW Portugal), la caractérisation du paléoenvironnement et du paléoclimat, ainsi qu'une tentative de corrélation avec d'autres dépôts du Pliocène. Cette localité est un site important pour comprendre la végétation et le paléoenvironnement du nord-ouest de la péninsule Ibérique au cours du Pliocène. Près de 70 taxons différents ont été identifiés (bryophytes, fougères, gymnospermes et angiospermes). Ils représentent principalement une paléo-zone humide dominée par une végétation arborescente vivant dans des conditions climatiques chaudes et humides. 


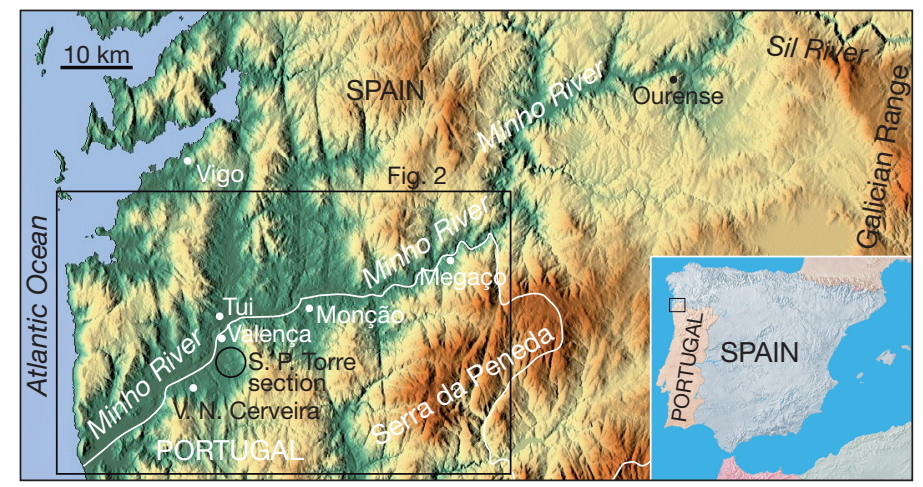

FIG 1. - Location map of Minho River Basin in the north-western Iberian Peninsula. The Minho River extends $300 \mathrm{~km}$ in a NE-SW orientation. It runs from Lugo (Spain), in the North, and terminates at the Atlantic Ocean after a $70 \mathrm{~km}$ course representing the border between Portugal and Spain. In the terminal sector, the Minho valley is strongly controlled by variscan faults and by tectonic depressions related to the movement of some post Alpine related faults.

\section{INTRODUCTION}

European Neogene fossil plant localities are currently the topic of recent investigations, which are providing important datasets in order to reconstruct the palaeofloras, palaeo-ecosystems and palaeoclimatic conditions (Diniz 1984; Ferguson 1988; Martinetto 1999; Meller et al. 1999; Bertini 2006; Kvaček 2007; Bertini \& Martinetto 2008; Barrón et al. 2010). The majority of the previous reconstructions are based on the preserved organs of woody plants, such as leaves, diaspores or palynomorphs.

During the Pliocene, at mid-latitudes, there was a progressive transition from a relatively warm and humid climate to the cooler climate experienced during the Pleistocene. The reconstruction of Pliocene vegetation and climate is important as during this time the average global temperature was significantly higher than at present (Fauquette et al. 1999).

In contrast to equivalent localities in Europe, scant palaeoecological information is documented in Portugal. In fact, during the twentieth century, few studies using palaeobotanical/palynological data were undertaken (Andrade 1945; Diniz 1984; Poças 2004; Pais et al. unpublished manuscript).

The most comprehensive palynological study conducted on Portuguese Pliocene sediments was undertaken by Diniz (1984) in the Rio Maior basin (North Lisbon); a tectonic basin infilled by sands and overlain by lignites and diatomites. The study of the Rio Maior basin was the first important contribution in characterizing the Plio-Quaternary vegetational history on the southern Europe Atlantic margin. Pollen analyses of two drill cores, situated in the axis of Rio Maior lacustrine basin, revealed a complex flora comprising Mediterranean, Atlantic and Macaronesian elements, including plants currently restricted to the subtropical regions of Asia and North America. It was possible to recognize nine separate floristic assemblages classified from A to I. These assemblages correspond to a progressive transformation of the flora, from relatively warm, humid climate taxa (A to D), into one with fewer thermophile plants, tolerant of rather humid conditions ( $\mathrm{E}$ and $\mathrm{F}$ ), and lastly, at the top of the sequence, the disappearance of the majority of subtropical elements (I), which corresponds to a cooling event. The magnetostratigraphical and palynological study of Abum (top of the Rio Maior sequence) allows the placement of the PiacenzianGelasian boundary in that section (Diniz \& Mörner 1995). It is clear that the subtropical elements are reduced and the vegetation impoverished, whilst the temperate taxa seem to dominate. The last levels (corresponding to assemblage I) indicate the degradation of vegetation; only Pinus, Ericaceae, Myrica and Alnus persist. Due to the richness in pollen data, this locality has been used as a reference section in the reconstruction of the Pliocene flora in Portugal (Diniz 1984). 


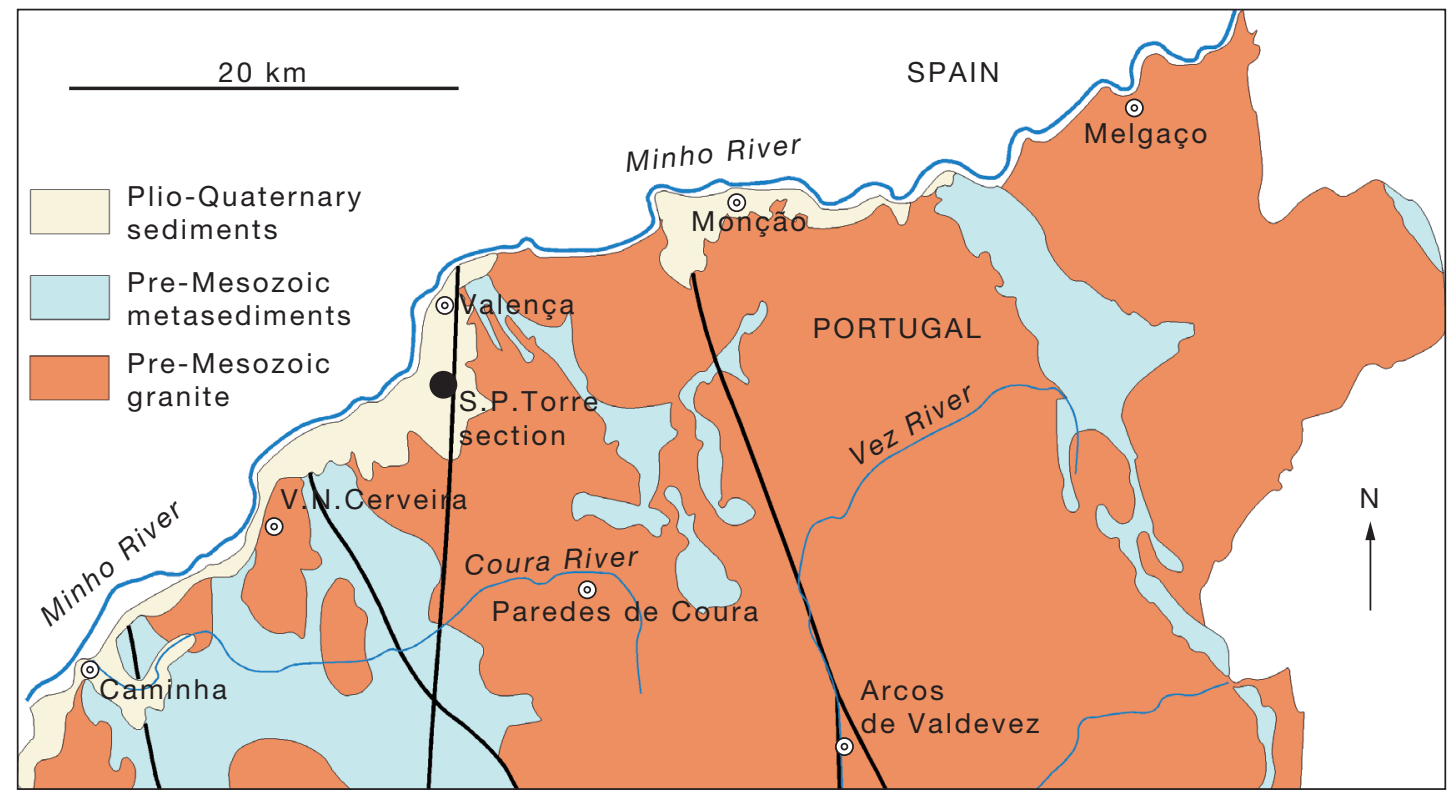

FIG 2. - Regional geological map of Northwest Portugal (adapted from the Geological Map of Portugal 1:1000000, LNEG, in publication).

In north-western Portugal, the Minho River Basin comprises sediments of Pliocene to recent age. The occurrence of black clays, containing charcoal fragments, has been documented since the 1940s. Montenegro de Andrade (1945) presented the first palynological study from the nearby $S$. Pedro da Torre (Valença)-Corgos site and documented the presence of light grey clay with woody fragments lying beneath a conglomeratic deposit. This author recognized a temperate flora including Pinus, Quercus, Castanea, Salix, Betula, "Pollen vestibulum", Asteraceae, Schizeaceae, Polypodiaceae, Cyatheaceae and other herbaceous plants. The stratigraphical position of this fossiliferous site is uncertain but, by his description, appears to be similar to that at S. Pedro da Torre.

Macrofossil remains recovered from the Barrocas site (S. Pedro da Torre, Valença) were studied in the late 1980's by João Pais and H. Gregor, but remain unpublished (Pais et al. unpublished manuscript). In 2004, Poças analyzed 2 samples from the same levels and identified 28 different taxa and only the high proportion of charcoal and organic matter hampered further identification of taxa.
The aims of this new study, utilising new data from the sediments at $S$. Pedro da Torre, are to conduct a systematic botanical description of the microfloral elements, to detail the palaeoenvironment and palaeoclimate and to investigate the potential for correlation with other Pliocene deposits.

\section{GEOLOGICAL SETTING}

The Minho River Basin occupies a significant area of north-western Iberia; extending from Galiza, Spain to the north of Portugal. The basin is $17080 \mathrm{~km}^{2}$ and includes the Sil sub-basin, which, prior to the confluence with the Minho River, is more extensive draining from the Galician Range (Fig. 1). This region forms part of the so-called Iberian Massif, comprising Precambrian-Palaeozoic basement rocks. The basement dominantly consists of granitoid intrusions and sediments, which were folded and metamorphosed during the Variscan Orogeny (Fig. 2).

The Minho River extends $300 \mathrm{~km}$ in a NE-SW orientation. It runs from Lugo (Spain), in the north, 


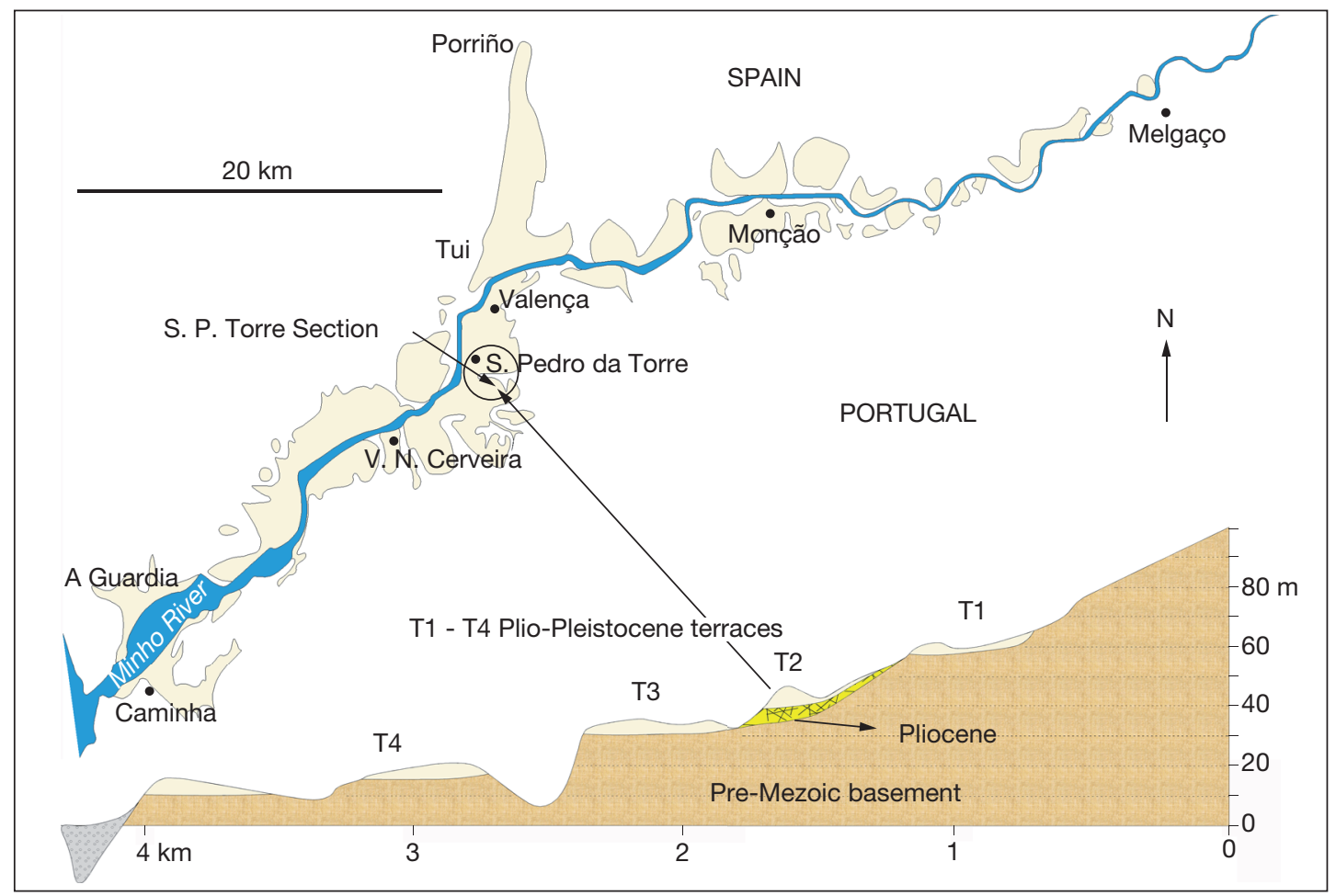

FIG. 3. - Fluvial deposits from Minho River Basin. The transverse profile represents the sediments from S. Pedro da Torre area. The studied samples are from the Pliocene sediments, underneath the Plio-Pleistocene fluvial terraces.

and terminates at the Atlantic Ocean after a $70 \mathrm{~km}$ course representing the border between Portugal and Spain. In the terminal sector, the Minho valley is strongly controlled by variscan faults and by tectonic depressions related to the movement of some post Alpine related faults.

The pre-Pleistocene Cenozoic deposits in the northwest Iberian Peninsula are limited and the sediments primarily infill small strike-slip basins running along N-S to NW-SE trending fault corridors. Attributing an age to these sediments is problematic due to the scarcity of fossils. A bed of green clay, collected from the basal infill of the As Pontes (Coruña) basin, was interpreted to be late Oligocene in age (zones MP 24-25) based upon fragments of micromammals (López-Martínez et al. 1993; Santanach 1994). The younger Pleistocene and Holocene deposits are located in the fluvial valleys (mainly in Minho valley) and close to the coast. These deposits comprise conglomerates with impersistent thin beds of sand and clay, which form fluvial terraces. In the lower beds, the clay composition is kaolinitic whilst the upper beds are illitic (Pereira 1991).

The present study is focussed on the S. Pedro da Torre fossiliferous level from the Cenozoic fluvial sedimentary record. This is preserved in a $4 \mathrm{~km}$ wide depression between Porriño (Spain) and V. N. Cerveira (Portugal) and is related to the N-S trending Pontevedra-Ponte de Lima fault corridor (Fig. 2). The geology of this region has been studied by several authors since 1944 (Teixeira 1944; Lautensach 1945; Nonn 1966, 1967; Carvalho 1981; Pereira 1989, 1991; Alves \& Pereira 2000). In this valley, a lower unit, comprising clays with rich, local horizons of lignites, sands and gravel, is covered by extensive fluvial gravel. These gravels are largely considered to be river terraces of Pleistocene age (Pereira 1989, 1991) (Fig. 3). In the Porriño sector, to the north 


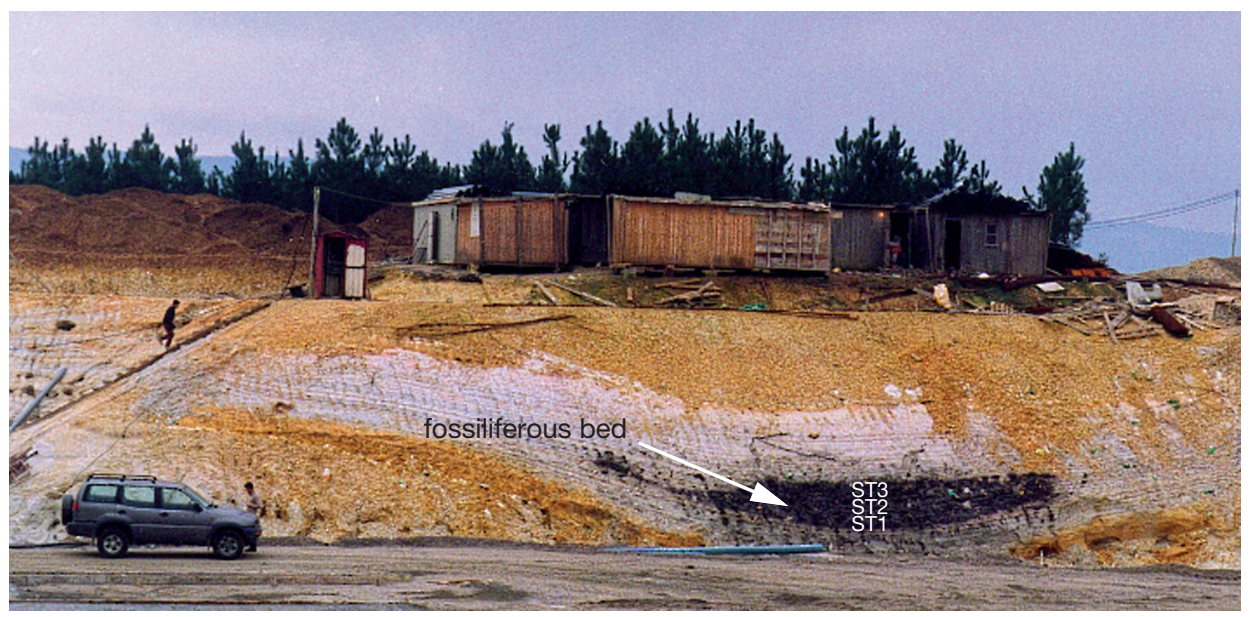

FIG. 4. - Fossiliferous site seen during the construction of the A3 highway, in S. Pedro da Torre (Valença, Portugal) showing the levels sampled ST1, ST2 and ST3.

of the depression, the lateral equivalent of the clay unit is thicker. A palynological study developed from the base of the lignite layer suggests a Tortonian age (late Miocene) (Nonn 1966). The flora recovered contained Arecaceae, Nyssa, Myrica, Rhus, Symplocos, Lygodium, Capparidaceae and Cupressaceae together with temperate elements like Castanea (Medus 1965; Nonn 1966). The basal deposits were predominantly explored in this area (Spanish territory) and described as similar to the $S$. Pedro da Torre deposits (Lautensach 1945; Nonn 1966).

The samples collected for this study came from a sedimentary level containing plant fossils, which was exposed during the $\mathrm{A} 3$ highway construction. The deposit comprises an interval of black clay intercalated with white clays, which are commonly exploited in the local area for ceramics. It was possible to collect part of the fossiliferous level, including some plant macro remains, shortly before the outcrop was reburied (Fig. 4).

\section{MATERIALS AND METHODS}

Three samples from the outcrop were collected for palynological study. All of them came from the same black clay layer (Fig. 4) and were labelled ST1, ST2 and ST3 from bottom to top. The method used for the extraction of pollen and spores from these samples was the standard chemical digestion technique involving standard $\mathrm{HCl}$ and $\mathrm{HF}$, using a 10 and $125 \mu \mathrm{m}$ sieve to remove fine and coarse fractions.

Due to the high proportion of charcoal and woody fragments it was necessary to subject the samples to chemical treatment with natrium perborate $\left(\mathrm{NaBO}_{2} \mathrm{H}_{2} \mathrm{O}_{2} 3 \mathrm{H}_{2} \mathrm{O}\right)$ in order to better observe, study and identify the palynomorphs. The purpose of this was to produce the most complete a floristic list possible. From all slides studied, some pollen grains were separated for single grain observation under Light Microscope (LM) and Scan Electronic Microscope (SEM), following the procedures outlined by Zetter (1989) and Vieira et al. (2009) for comparative morphologic study. Between 690 and 830 pollen grains and spores were counted per sample (Table 1).

\section{FLORAL CONTENT}

The sediment collected contained abundant leaves of Taxodium and Liquidambar (Fig. 5), fruits and seeds of Salvinia, Taxodium, Symplocos, Eurya, Tilia, Rubiaceae and Apiaceae. In a preliminary palynological evaluation when the outcrop was exposed, one of the authors (J. Pais) recognized pollen grains of Salvinia, Pinus, Picea, Taxodiaceae, Symplocos, Liquidambar, Engelhardia, Carya, Quercus, Ericaceae and Poaceae. 
TABLE 1. - List of pollen taxa identified in S. Pedro da Torre (including absolute pollen count).

\begin{tabular}{|c|c|c|c|c|}
\hline \multirow[b]{2}{*}{ Family } & \multirow[b]{2}{*}{ Genus } & \multicolumn{3}{|c|}{ Samples } \\
\hline & & ST1 & ST2 & ST3 \\
\hline \multirow[t]{2}{*}{ Anthocerotaceae } & Anthoceros & 1 & 0 & 2 \\
\hline & Phaeoceros & 1 & 0 & 1 \\
\hline Ricciaceae & Riccia & 1 & 0 & 0 \\
\hline Sphagnaceae & Sphagnum & 3 & 2 & 1 \\
\hline Selaginellaceae & Selaginella & 1 & 3 & 4 \\
\hline Cyatheaceae & & 0 & 1 & 0 \\
\hline Gleicheniaceae & & 2 & 0 & 1 \\
\hline Osmundaceae & Osmunda & 1 & 1 & 1 \\
\hline Polypodiaceae & Polypodium & 13 & 5 & 9 \\
\hline \multirow[t]{2}{*}{ Pteridaceae } & & 31 & 39 & 24 \\
\hline & Pteris & 2 & 9 & 8 \\
\hline \multirow[t]{4}{*}{ Pinaceae } & Cathaya & 19 & 41 & 36 \\
\hline & Picea & 3 & 7 & 8 \\
\hline & Pinus & 293 & 333 & 376 \\
\hline & Tsuga & 0 & 1 & 0 \\
\hline \multirow{2}{*}{ Cupressaceae } & & 3 & 5 & 1 \\
\hline & Junip & 0 & 0 & 4 \\
\hline Taxodiaceae & Taxodium type & 3 & 11 & 7 \\
\hline \multirow[t]{2}{*}{ Sapindaceae } & Acer & 4 & 0 & 1 \\
\hline & Acer negundo & 1 & 0 & 0 \\
\hline Aquifoliaceae & Ilex & 4 & 2 & 6 \\
\hline \multirow{2}{*}{ Betulaceae } & Alnus & 2 & 1 & 3 \\
\hline & Betula & 0 & 1 & 2 \\
\hline \multirow[t]{3}{*}{ Oleaceae } & & 4 & 1 & 3 \\
\hline & Castanea & 22 & 28 & 40 \\
\hline & Quercus & 21 & 23 & 33 \\
\hline & Liquidambar & 109 & 113 & 125 \\
\hline \multirow{5}{*}{ Juglandaceae } & Carya & 4 & 1 & 3 \\
\hline & Engelhardia & 61 & 59 & 58 \\
\hline & Juglans & 11 & 31 & 11 \\
\hline & Pterocarya & 63 & 0 & 2 \\
\hline & Platycarya & 0 & 0 & 5 \\
\hline Adoxaceae & Sambucus & 0 & 0 & 2 \\
\hline Cercidiphyllaceae & Cercidiphyllum & 0 & 1 & 0 \\
\hline
\end{tabular}

\begin{tabular}{llccc}
\hline & & \multicolumn{3}{c}{ Samples } \\
Family & Genus & ST1 & ST2 & ST3 \\
\hline Myricaceae & Myrica & 4 & 9 & 9 \\
Cornaceae & cf. Diplopanax & 0 & 1 & 0 \\
& Nyssa & 3 & 7 & 1 \\
Rutaceae & & 2 & 1 & 2 \\
& Citrus & 1 & 0 & 0 \\
Salicaceae & Salix & 0 & 1 & 0 \\
Sapotaceae & & 3 & 1 & 0 \\
Symplocaceae & Symplocos & 9 & 16 & 9 \\
Malvaceae & Tilia & 1 & 0 & 0 \\
Ulmaceae & Ulmus & 0 & 1 & 0 \\
Amaranthaceae & & 0 & 2 & 0 \\
Apiaceae & & 2 & 1 & 0 \\
Araliaceae & Hedera & 7 & 1 & 3 \\
Asteraceae & & 3 & 2 & 3 \\
Campanulaceae & Campanula & 1 & 0 & 0 \\
Caryophyllaceae & & 0 & 2 & 1 \\
Cistaceae & & 4 & 4 & 0 \\
& Cistus & 1 & 0 & 0 \\
Convulvulaceae & & 0 & 0 & 1 \\
Dipsacaeae & Scabiosa & 0 & 1 & 0 \\
Ericaceae & & 4 & 4 & 6 \\
Euphorbiaceae & & 1 & 0 & 2 \\
Fabacaeae & & 1 & 0 & 0 \\
Haloragaceae & Myriophyllum & 0 & 1 & 0 \\
Santalaceae & Viscum & 0 & 1 & 0 \\
Onagraceae & & 0 & 1 & 0 \\
Plantaginaceae & Plantago & 0 & 1 & 0 \\
Nymphaeaceae & Nuphar & 1 & 0 & 2 \\
Poaceae & & 2 & 3 & 0 \\
Polygalaceae & & 2 & 0 & 0 \\
Typhaceae & Typha & 3 & 0 & 2 \\
Vitaceae & Parthenocissus & 3 & 1 & 4 \\
Gen. indet. & & 9 & 12 & 8 \\
\hline TOTAL & & $\mathbf{6 9 0}$ & $\mathbf{7 9 3}$ & $\mathbf{8 3 0}$ \\
\hline & & & &
\end{tabular}

This deposit has been the subject of a previous palynological study conducted by Poças (2004). The author indentified and described 28 pollen taxa belonging to: Anthoceros, Lycopodium, Polypodiaceae, Pinus, Cathaya, Tsuga, Taxodiaceae, Cupressaceae, Ephedra, Alnus, Castanea, Quercus, Myrica, Carya, Engelhardia, Juglans, Pterocarya, Acer, Oleaceae, Liquidambar, Tilia, Ericaceae, Ilex, Poaceae, Amaranthaceae/Chenopodiaceae, Cistaceae, Asteraceae and Cyperaceae.

In the present study, following the chemical treatment with natrium perborate to remove the charcoal content from the samples, 40 additional pollen and spore taxa were identified for the first time in these sediments. After counting 2313 palynomorphs with a

good preservation, the recognized fossil flora included plants from approximately 70 different microfloral elements, characterized by hepatophytes, anthocerophytes, bryophytes, lycophytes, pterydophytes, gymnosperms and angiosperms (Table 1).

The studied samples show few differences in their microfloral composition, based predominantly on small changes in percentage of the most frequently found elements (Pinus, Liquidambar, Juglandaceae, Pteridaceae and Symplocos) and the associated forms. The arboreal pollen (AP) to non-arboreal pollen (NAP) ratio shows that arboreal pollen is clearly dominant, indicating a highly forested area (Fig. 6).

By examining the distribution of key taxa more closely, spores were found regularly in the stud- 

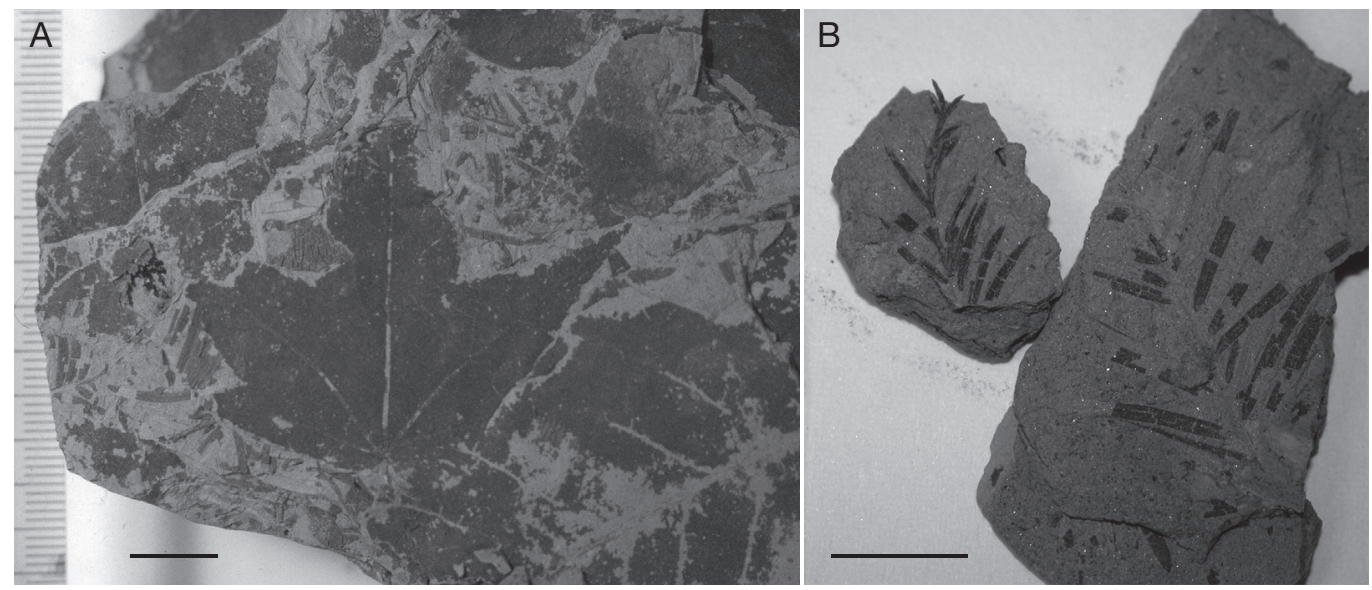

FIG. 5. - Plant remains from S. Pedro da Torre (Valença, Portugal): A, Liquidambar europaea; B, Taxodium hantkey. Scale bars: $\mathrm{A}, \mathrm{B}, 1 \mathrm{~cm}$.

ied samples. These consisted of Pteridaceae (most abundant), Polypodiaceae, Selaginellaceae, and less frequent Osmundaceae, Gleicheniaceae and Cyatheaceae. The Bryophyta spores, such as Sphagnum or Anthocerophytes (Anthoceros and Pheoceros) and Hepatophyte (Riccia), have a minor occurrence. This high and diverse representation of spores seems to indicate a humid or swampy environment.

In the case of gymnosperms, the pollen of Pinaceae dominates the assemblage and were identified as Pinus (most abundant in the pollen spectra) with Cathaya well represented. The observed percentage (approximately 45\%) is presumably due to the capacity of bisaccate pollen to experience a long distance transport.

Other gymnosperms (Picea, Tsuga, Taxodiaceae and Cupressaceae) are present in small quantities, testifying to the presence of mid- and/or high-altitude forests, the presence of which is also important for the regional vegetation. In the macroremains, Taxodium leaves appear relatively more frequent than pollen, which his probably due to the poor preservation of the Taxodiaceae grains within the samples studied.

Angiosperm tree and shrub pollen is abundant and diverse within the pollen spectra, and is essential in the characterization of this pollen assemblage. The herbs are represented in lesser

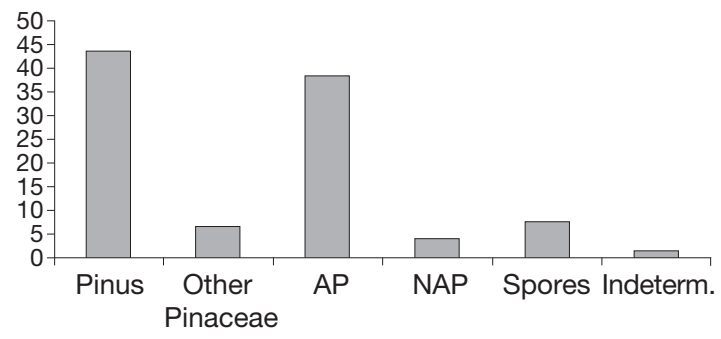

FIG. 6. - Percentage of the main groups of pollen and spores from S. Pedro da Torre. Abbreviations: AP, arboreal forms; NAP, non arboreal forms.

proportions, thus testifying to a dominance of forest-type vegetation in the areas surrounding the paleo-lake/channel.

The Hamamelidaceae appear to dominate; represented by different types of Liquidambar pollen (Fig. 7), which is confirmed by the abundance of Liquidambar leaf prints in the sediment. Juglandaceae pollen is also highly abundant, including the genera Engelhardia and Juglans, with subordinate Carya, Platycarya and Pterocarya.

The Fagaceae family is well represented in the palynological assemblage by Castanea and Quercus. It was possible to distinguish Quercus pollen from other deciduous and evergreen taxa (Fig. 8) using SEM. The ability to distinguish evergreen from 
TABLE 2. - Vegetation types present in S. Pedro da Torre (adapted from Bertini, 2002).

\begin{tabular}{|c|c|c|}
\hline Type of vegetation & Characteristic floral elements & Description \\
\hline $\begin{array}{l}\text { "Subtropical" humid forest/ } \\
\text { Para-tropical elements }\end{array}$ & $\begin{array}{l}\text { Taxodiaceae, Engelhardia, Nyssa, } \\
\text { Symplocos, Myrica, Sapotaceae, } \\
\text { Diplopanax, Rutaceae, Cathaya, etc. }\end{array}$ & $\begin{array}{l}\text { Species living under a climatic regime with a } \\
\text { small range of temperature and abundant and } \\
\text { well-distributed rainfall throughout the year. }\end{array}$ \\
\hline $\begin{array}{l}\text { Temperate broad-leaved } \\
\text { deciduous forest }\end{array}$ & $\begin{array}{l}\text { Acer, Liquidambar, Carya, Juglans, } \\
\text { Pterocarya, Quercus, Castanea, etc. }\end{array}$ & $\begin{array}{l}\text { Species living under a climate with a cold win- } \\
\text { ter season and a warm summer season and } \\
\text { adequate precipitation in all months. }\end{array}$ \\
\hline Sclerophyll forest & Oleaceae, Cupressaceae & $\begin{array}{l}\text { Xerophylous hard leaved trees and shrubs, } \\
\text { which live in areas with a wet winter and dry } \\
\text { summer (Mediterranean). }\end{array}$ \\
\hline Mid to high altitude forest & Tsuga, Picea & $\begin{array}{l}\text { Elements usually present in cold continental } \\
\text { climates; seem to come from mountain chains } \\
\text { in surrounding areas. }\end{array}$ \\
\hline Open vegetation & $\begin{array}{l}\text { Amaranthaceae, Poaceae, Cistaceae, } \\
\text { Ericaceae, Caryophyllaceae, etc. }\end{array}$ & $\begin{array}{l}\text { Grasses and herbs that indicate open vegeta- } \\
\text { tion, dry climatic conditions or coastline vege- } \\
\text { tation. }\end{array}$ \\
\hline
\end{tabular}

deciduous oak pollen is critical for a more accurate paleoecological interpretation of Tertiary assemblages (Leopold \& Clay-Poole 2001). Denk \& Grimm (2009) demonstrated that pollen identification is among the most important morphological characters that define the major infrageneric groups within oaks (i.e. Ilex, Cerris, Cyclobalanopsis, Quercus, Lobatae and Protobalanus). In general, when relying on LM only, the low resolution of this instrument and the possible occurrence of more diverse types of fossil oak pollen than present in Portugal/Europe today, or even a higher diversity, in terms of morphological variability, constitute a problem in their identification.

A wide range of species that retain their leaves throughout the year are referred to as "evergreen oaks". These are present in the Mediterranean, the Himalayas, East Asia, large mountainous regions of southwest China (at an altitude of 2600-4000 $\mathrm{m})$, and North America. The Quercus pollen identified in this deposit suggest the palaeovegetation could have comprised a mixture of both evergreen and deciduous types. The Quercus pollen D, E, F, illustrated in Figure 8 has similar morphology with some Quercus types shown by Liu et al. (2007), Denk et al. (2010) and Solomon (1988a, b). It is likely to have belonged to a white oak or to the phylogenetic lineage including the infrageneric groups Protobalanus, Quercus and Lobatae. The
Quercus pollen A, B, C, illustrated in Figure 8 has similar features to the ones included in the Ilex phylogenetic lineage.

Aquatic plants are closely connected to swamp areas, and are represented here in small quantities (Typha, Myriophyllum and Nuphar). Herbaceous angiosperms are represented by many taxa belonging to the family Asteraceae, Cistaceae, Apiaceae, Poaceae, etc. Rare Ericaceae pollen appears to indicate a highly forested area, when compared to other Portuguese localities (Diniz 1984; Vieira 2009). Woody climbers such as Hedera and Parthenocissus are also present.

\section{DisCUSSION}

Palynological and macrofossil assemblages are particularly useful in reconstructing vegetation and paleoenvironments from the Pliocene of Europe. In this paper we adopt informal biome/vegetation units known as "formation classes" which have been already developed and used by many other palynologists (e.g., Suc et al. 1995a, b, 1999; Bertini 2002). Based on the pollen flora, five principal "formation classes" have been described for this region (Table 2).

Only a few taxa will be discussed here due to particular ecological or stratigraphical attributes.

Engelhardia (Juglandaceae) (Fig. 9) is common in pollen records from the lower Pliocene (Bertini 

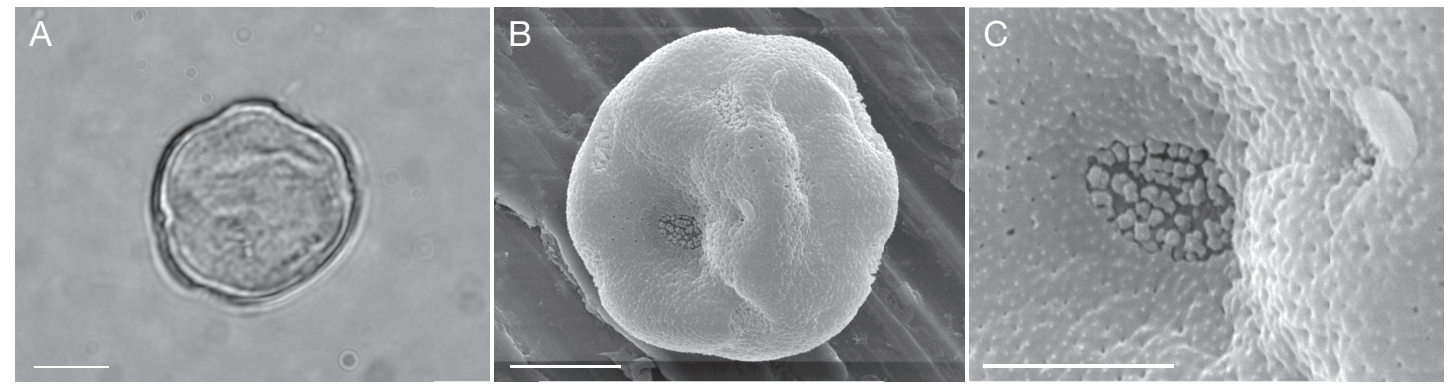

Fig. 7. - Liquidambar sp. pollen: A, LM view; B, SEM view; C, detail of the exine surface. Scale bars: A, B, $10 \mu \mathrm{m}$; C, $5 \mu \mathrm{m}$.
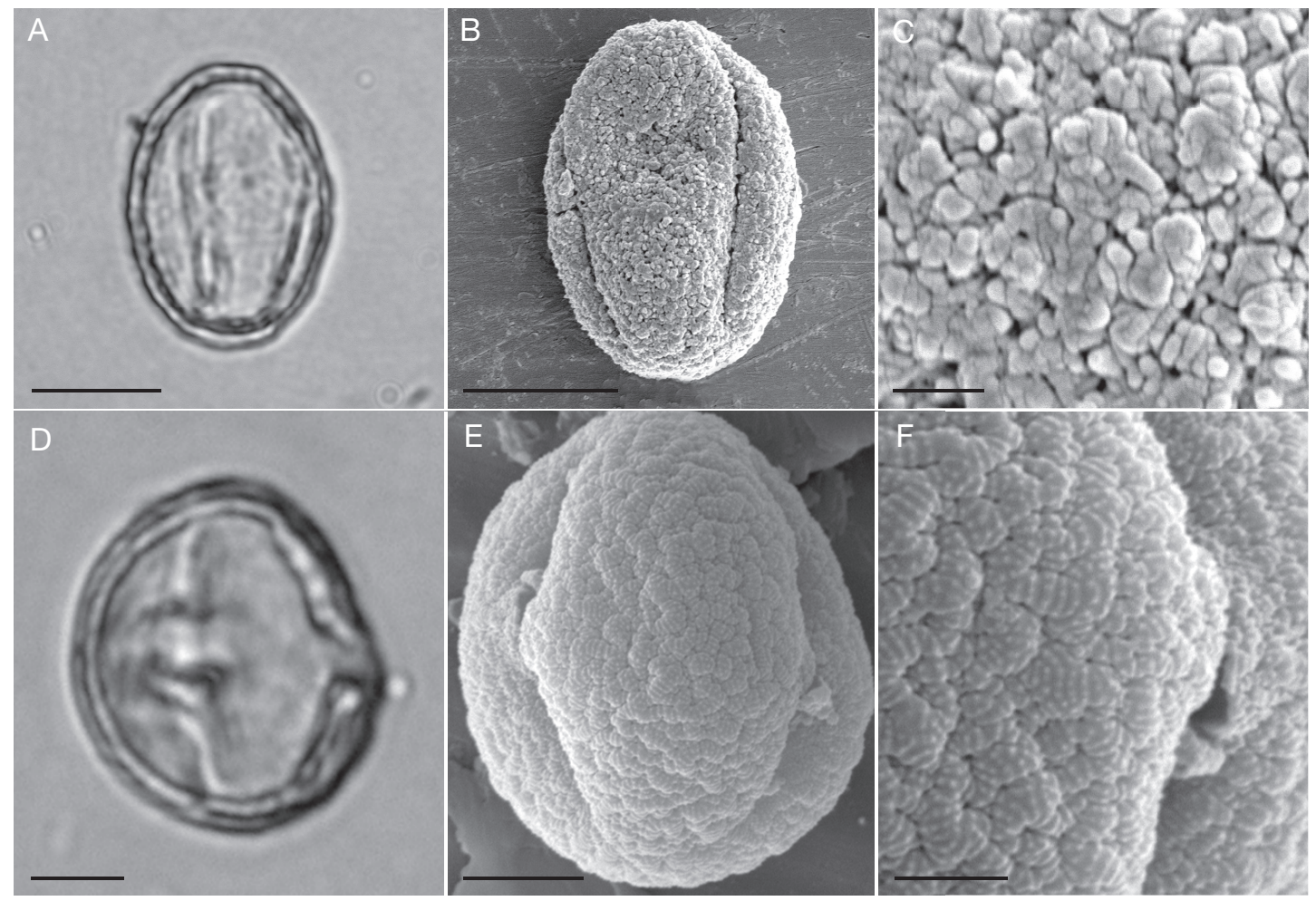

Fig. 8. - Quercus sp. pollen: A, D, equatorial view in LM; B, E, equatorial view in SEM; C, F, detail of the exine surface. Scale bars: A, B, $10 \mu \mathrm{m} ; \mathrm{C}, 1 \mu \mathrm{m} ; \mathrm{D}, \mathrm{E}, 5 \mu \mathrm{m} ; \mathrm{F}, 2 \mu \mathrm{m}$.

2006; Fauquette et al. 2006), with fruits reported from the evaporitic Messinian and the Zanclean (Martinetto 1999). These ancient plants correspond to semi-evergreen or summer-green trees growing under "subtropical" to warm-temperate conditions (Kvaček 2007), but now inhabit tropical regions.
Such ecological and climatic interpretations are in agreement with pollen records from many European localities (Fauquette et al. 1998; Suc et al. 1999; Bertini 2006).

Myrica (Myricaceae), Nyssa (Nyssaceae) and Symplocos (Symplocaceae) (Fig. 10) are common 

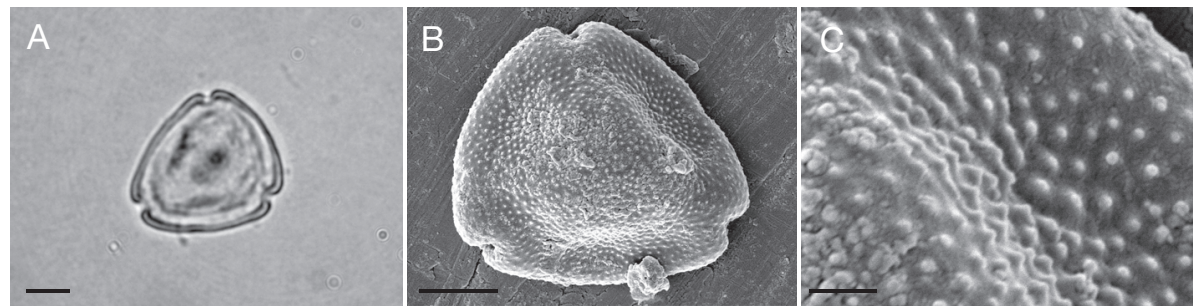

Fig. 9. - Engelhardia sp. pollen: A, LM equatorial view; B, SEM equatorial view; C, detail of the exine surface. Scale bars: A, B, $5 \mu$ m; C, $1 \mu \mathrm{m}$.

and interpreted as "subtropical" to warm temperate deciduous woody plants living under the yearlong humid edaphically environment commonly associated with Taxodium. These genera are usually present in Miocene and Pliocene pollen records from Southern Europe and are interpreted to have been arboreal plants living in humid areas with subtropical conditions (Bertini 1992; Bertoldi et al. 1994). Today, Nyssa trees are only present in China, Indonesia and Oriental North America, e.g., Florida (Li 1952). They are mega-mesothermic plants, which usually live in lowlands. In China, this genus lives within a warm and humid climate and can be found associated with the genera Symplocos, Engelhardia and Glyptostrobus. In Florida it occurs associated with Taxodium, Myrica, Carya, Juglans, Liquidambar, etc. According to Mai (1995) Nyssa and Taxodium, together with various other elements, are the main component of fossil swamp forests in the European Oligocene and Miocene. These two elements are still important in presence in Portuguese sediments during the Upper Pliocene (Vieira 2009).

Liquidambar trees are native from Florida but can be found in Mexico and East Asia, where they occur in humid regions with a subtropical climate. In Florida, it is common to see Liquidambar, associated with Taxodium trees, in swamp areas. This association is also seen in this instance, confirming the existence of a swamp/humid environment.

The genus Cathaya is today restricted to China and grows between 300 and 1800 meters in elevation, in subtropical climates with approximate annual temperatures of $15-21^{\circ} \mathrm{C}$ and precipitation levels of 1300-2000 mm (Van Campo 1979). In the Pliocene this genus is common amongst other mesothermic taxa (e.g., Tsuga and Cedrus) (Vieira 2009).

Tsuga (Fig. 11) presently occur in both North America and South-East Asia. These trees usually need high humidity levels throughout the year at elevations of greater than 2500 meters (Wang 1961).

Eurya (Theaceae), identified in the macro-remains, is now native to southern and Eastern Asia and the Pacific islands. This supports the interpretation of a sub-tropical climate.

Diplopanax, a genus of flowering tree, is known from two extant species that inhabit the wet tropical mountains of Vietnam and southern China. They are broad-leaved evergreen trees with woody fruits and white or yellow flowers. They are generally placed into the Cornaceae family, and also sometimes separated, along with the genus Mastixia, into the family Mastixiaceae (Fan \& Xiang 2003). This genus is cited to document the climatic optimum occurring in Central and West Europe during the early-middle Miocene and became extinguished from Central Europe during the upper Miocene as a result of the cooling that took place in the upper Serravallian (Ševčík et al. 2007). Its occurence at this latitude in the Pliocene, shows that the warm and humid climatic conditions, which prevaled in most of the European area until the upper Miocene, still existed in the NW of Portugal at that time. The proximity to the Atlantic Ocean seems to have had an important effect on the vegetation dynamics during the Pliocene, as it does in present times.

From the total pollen content, a broadleaved evergreen/warm mixed forest, similar to modern ones living today in eastern China or in Florida, can be inferred. This suggests relatively stable cli- 

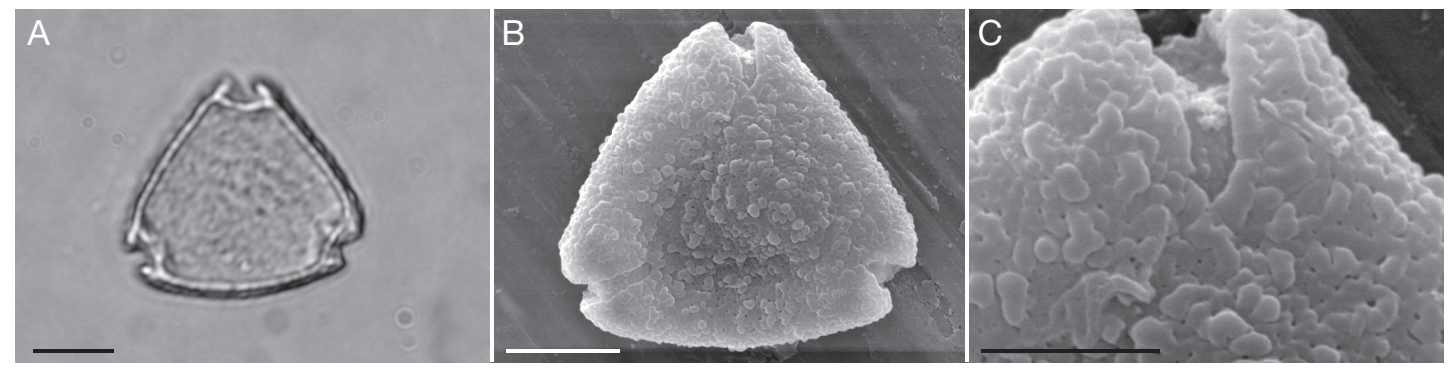

Fig. 10. - Symplocos sp. pollen: A, LM equatorial view; B, SEM equatorial view; C, detail of the exine surface. Scale bars: A, B, $10 \mu$ m; C, $1 \mu \mathrm{m}$.
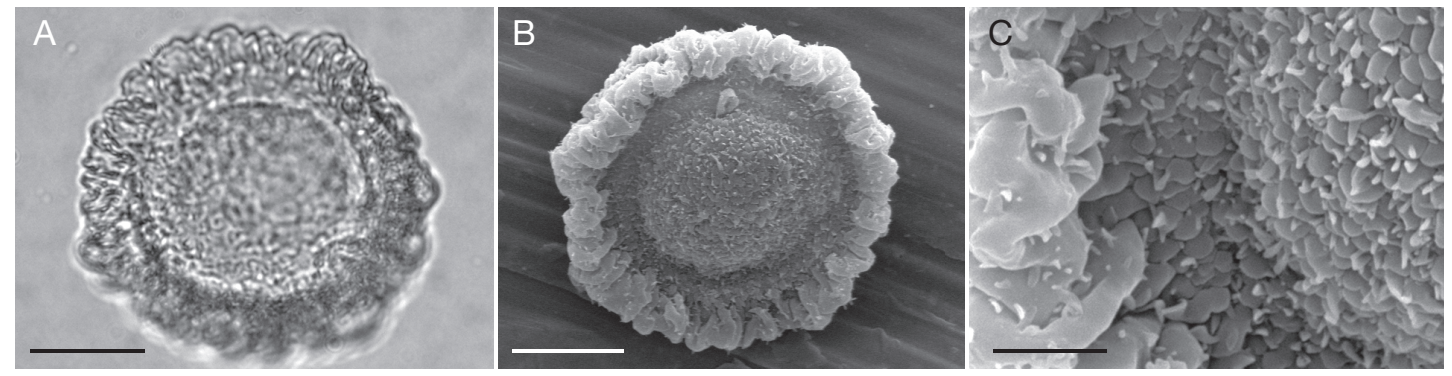

FIG. 11. - Tsuga sp. pollen: A, LM view; B, SEM view; C, detail of the exine surface. Scale bars: A, B, $20 \mu \mathrm{m} ; \mathrm{C}, 5 \mu \mathrm{m}$.

matic conditions characterized by forest vegetation, typical from a humid warm-temperate climate. Nevertheless, the slight contrast between paratropical elements (e.g., Engelhardia, Taxodium) and mesomicrothermic species (Tsuga, Picea) may suggest moderate temperature fluctuations or the presence of distally located mountain areas.

Swamp vegetation is consistently documented by Taxodium and Liquidambar, followed by Nyssa, and Symplocos. The presence of trees such as Alnus or Salix seems to indicate the presence of flooded areas or riparian forests closely connected to the swamp. The high volume of Pteridaceae and low volume of Polypodium are frequently associated with these plant communities; living in their undergrowth or even in partly open places. From a pollen spectra recovered from the clay sediments (indicative of a high standing water table and/or lake environment) it is possible to infer that the distribution of this vegetation was mainly limited to the shore-side of a lake or surrounding small marshy ponds.
When examining the percentages of the main floral elements (Fig. 12), temperate species appear to outnumber the para-tropical ones. This fact can be explained by the unusual high number of Liquidambar pollen in the sediment in comparison to Taxodiaceae pollen. The preservation of Taxodiaceae pollen is not as good as Liquidambar but in the sediment the Taxodiaceae is highly abundant. In fact, upon comparison of the Quercus and Engelhardia record, Engelhardia pollen shows more than twice the abundance compared to Quercus, reflecting the profusion of this evergreen tree (Fig. 12).

It is possible to correlate this floral association to the lower part (Lower Piacenzian) of the recently re-studied (Vieira 2009) Rio Maior sequence (the reference basin for the Portuguese Pliocene) using the abundance of para-tropical elements and vegetation types. Both these localities characterize a diverse, mixed, forest dominated by several evergreen taxa, with additional temperate elements. These results seem to confirm the presence of swamp environments, developed in a very moist 

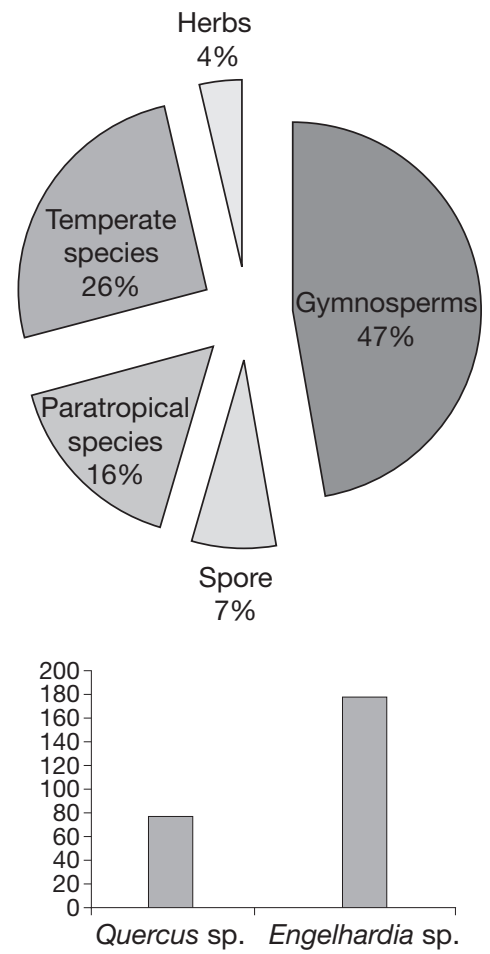

FIG. 12. - Percentage of the main floral elements. The ordinate is the absolute pollen number.

(due to the proximity to the Atlantic) subtropical environment, on the Portuguese Atlantic coast during the Upper Pliocene. At the same time, an expansion of Mediterranean-type taxa can be seen in several locations in the eastern Iberian Peninsula (Barrón et al. 2010). Palaeobotanical studies of the Piacenzian of Catalonia (Suc \& Cravatte 1982; Solé de Porta \& Valle 1986; Bessais \& Cravatte 1988) revealed the existence of a diverse vegetation that pointed to the progressive decrease of several para-tropical taxa in favour of Mediterranean elements (Olea, Phyllirea and Cistaceae). Evidence also exists for the reduction of the tree component, giving way to prairies and steppes, as characterised by AmaranthaceaeChenopodiaceae, Poaceae and different Asteraceae, such as Armeria (Suc \& Cravatte 1982; Bessais \& Cravatte 1988).

Recently a large amount of plant fossils were described from northern Spain by Alcade Olivares et al. (2004). These sediments cropped out during the construction of the "Cantábrico" highway near Caranceja. Several small fragments of charcoal and wood, alongside seven pollen samples, were studied. The presence of the extinct taxa (Taxodiaceae) enabled the authors to improve the dating from a previous geological study and to date the Caranceja fossil remains to the latest Pliocene. The Caranceja study has revealed a mixed forest with many conifers (Taxodiaceae, Cupressaceae, and Pinaceae) and angiosperms, such as Betula, Castanea, Quercus and Fagus, in this area. Upon comparison of the Upper Pliocene results from $S$. Pedro da Torre with Caranceja in Cantabria, we notice that the vegetation has a more temperate character in Caranceja. Despite the difference in geographical position, the S. Pedro da Torre succession must be older than the ones in Cantabria due to the floristic association.

Recent studies of several outcrops and cores from the Pliocene of the Portuguese Atlantic margin have led to a better understanding of the history of vegetation and evolution of climatic conditions of this region. Palynological analysis reveals a complex and diverse flora, which today is found in climatically contrasting regions. Several important climatic indicators were identified such as: Engelhardia, Nyssa, Taxodiaceae, Tsuga, Symplocos, Zanthoxylum, Trigonobalanopsis, Cercidiphyllum, Craigia, and Mortoniodendron, for the Piacenzian. All these taxa grown in subtropical-warm temperatures and wet climates until the Piacenzian. In the Upper Piacenzian, paratropical elements became rare and progressively disappeared, having been substituted by temperate species (Vieira 2009).

\section{CONCLUSIONS}

The results of this study appear to support the hypothesis of Nonn (1966); that there must be a thick sedimentary unit, extending in an age, from the Tortonian (attributed by Medus [1965]) to the Pliocene, represented in the Porriño-Vila Nova de Cerveira basin. This particularly dark clay layer, in S. Pedro da Torre, seems to represent a small marshy pond surrounding a main river channel. 
It's proximity to the Atlantic Ocean would have created warm and humid climatic conditions as a product of the associated rainfall and humidity. This allowed the development of a mixed swamp/ riparian vegetation dominated by Taxodium and Liquidambar.

The comparison of this assemblage with other Upper Pliocene localities in south Europe reveals the exclusive nature of the flora at this site. While many localities, in southern Spain, are characterized by the development of the Mediterranean vegetation, the floral content at this locality, points to more humid conditions.

It is consensual that at the end of the Piacenzian, and throughout the Gelasian, progressive cooling became more intense. These falls in temperature have been related to the extinction of many subtropical taxa (Lisiecki \& Raymo 2005). Comparing the abundance of subtropical taxa recorded with the pollen data from Rio Maior basin (Vieira 2009), this deposit cannot be younger than the Piacenzian (Upper Pliocene).

\section{REFERENCES}

Alcalde Olivares C., Mercedes G. A., Fernando G. M. \& CARlos M. J. 2004. - Palaeoenvironmental interpretation of the Neogene locality Caranceja (Reocín, Cantabria, N Spain) from comparative studies of wood, charcoal, and pollen. Review of Palaeobotany and Palynology 132: 133-157.

Alves M. I. C. \& Pereira D. I. 2000. — A sedimentação e a gliptogénese no registo Cenozóico continental do Minho (NW Portugal). Ciências da Terra (UNL), 14: 101-111.

ANDRADE M. 1945. - Alguns elementos para o estudo do terraço superior do rio Minho. Boletim da Sociedade Geológica de Portugal, IV (3): 221-222.

Barrón E., Rivas-Carballo R., Postigo M. J., Alcalde-Olivares C., Vieira M., Castro L., Pais J. \& Valle-Hernadez M. F. 2010. - The Cenozoic vegetation of the Iberian Peninsula. A synthesis. Review of Palaeobotany and Palynology 162: 382-402.

BERTINI A. 1992. - Palinologia ed aspetti ambientali del versante adriatico dell'Appennino centro-settentrionale durante il Messiniano e lo Zancleano. Unpublished PhD Thesis, University of Modena, Italy, $88 \mathrm{p}$.

BERTINI A. 2002. - Palynological evidence of upper neogene environments in Italy. Acta Universitatis Carolinae-Geologica 46: 15-25.
BerTini A. 2006. - The Northern Apennines palynological record as a contribute for the reconstruction of the Messinian palaeoenvironments. Sedimentary Geology 188/189: 235-258.

Bertini A. \& MartinetTo E. 2008. - Messinian to Zanclean vegetation and climate of Northern and Central Italy. Bolletino della Società Paleontologica Italiana, 47 (2): 105-121.

Bertoldi R., BinOtTI A. \& CASTELlo F. 1994. - Reevesia and Itea in the pollen flora of the Upper Neogene continental deposit at Sarzana (lower Magra valley, Northern Italy). Review of Palaeobotany and Palynology 80 (1/2): 159-172.

Bessais E. \& Cravatte J. 1988. — Les écosystèmes végétaux pliocènes de Catalogne méridionale. Variations latitudinales dans le domaine Nord-Ouest Méditerranéen. Geobios 21: 49-63.

CARVAlHo G. S. 1981. - Uma metodologia para a análise dos depósitos do Quaternário. Arqueologia, 4: 50-63.

Denk T. \& Grimm G. W. 2009. - Significance of pollen characteristics for infrageneric classification and phylogeny in Quercus (Fagaceae). International Journal of Plant Science 170 (7): 926-940.

Denk T., Grímsson F. \& ZetTER R. 2010. — Episodic migration of oaks to Iceland: evidence for a North Atlantic "land bridge" in the latest Miocene. American Journal of Botany 97 (2): 276-287.

DINIZ F. 1984. - Apports de la palynologie à la connaissance du Pliocène portugais. Rio Maior: un bassin de référence pour l'bistoire de la flore, de la végétation et du climat de la façade atlantique de l'Europe meridionale. $\mathrm{PhD}$ Thesis, Université des Sciences et Techniques du Languedoc, Montpellier, $230 \mathrm{p}$.

Diniz F. \& MÖRNER N.-A. 1995. - The Reuverian/ Pretiglian transition in Rio Maior, Portugal. XIV International Congress INQUA, Schriften der AlfredWegner-Stiftung 2/95: 64.

FAN C. Z. \& XIANG Q. Y. 2003. - Phylogenetic analyses of Cornales based on 26S rRNA and combined 26S rDNA-matK-rbcL sequence data. American Journal of Botany 90: 1357-1372.

FauQueTte S., QuÉZel P., GUIOT J. \& SuC J.-P. 1998. Signification bioclimatique de taxons-guides $\mathrm{du}$ Pliocène méditerranéen. Geobios 31: 151-169.

Fauquette S., Suc J.-P., Guiot J., Diniz F., Feddi N., Zheng Z., Bessais E. \& Drivaliari A. 1999. Climate and biomes in the West Meditteranean area during the Pliocene. Palaeogeography, Palaeoclimatology, Palaeoecology 152: 15-36.

Fauquette S., SuC J.-P., Bertini A., Popescu S.-M., Warny S., Bachiri Taouid N., Perez Villa M., Chikli H., Subally D., Feddi N., Clauzon G. \& FERRIER J. 2006. - How much the climate forced the Messinian salinity crisis? Quantified climatic conditions from pollen records in the Mediterranean 
region. Palaeogeography, Palaeoclimatology, Palaeoecology 238: 281-301.

Ferguson D. K. 1998. - Case studies in the Cenophytic Palaeobotany of Central Europe. Review of Palaeobotany and Palynology 101: 1-286.

KVAČEK Z. 2007. - Do extant nearest relatives of thermophile European Cenozoic plant elements reliably reflect climatic signal? Palaeogeography, Palaeoclimatology, Palaeoecology, 253: 32-40.

LAUTENSACH H. 1945. - Formaçao dos terraços interglaciários do norte de Portugal e suas relaçóes com os problemas da época glaciária. Publicaçôes, Sociedade Geológica de Portugal I, 39 P.

LEOPOLD E. B. \& Clay-PoOle S. T. 2001. — Florissant leaf and pollen floras of Colorado compared: climatic implications. Proceedings of the Denver Museum of Nature and Science, Ser. 4 (1): 17-69.

Li H. 1952. - Floristic relationships between Eastern Asia and Eastern North America. Transactions of the American Philosophical Society, 42, 2: 371- 429.

Liu Y. S., Zetter R., Ferguson D. K. \& Mohr B. A. R. 2007. - Discriminating fossil evergreen and deciduous Quercus pollen: a case study from the Miocene of eastern China. Review of Palaeobotany and Palynology 145: 289-300.

LisIECKI L. E. \& RAYMO M. E. 2005. - A PliocenePleistocene stack of 57 globally distributed benthic $\delta^{18} \mathrm{O}$ records. Paleoceanography 20, PA1003. doi: 10.1029/2004PA001071.

López-Martínez N., Fernandez Marron M. T., PelaezCampomanez P. \& PeÑa Zarzuelo A. 1993. - Estudio paleontologico en las cuencas terciarias de Galicia. Revista de la Sociedad Geológica de España 6 (3/4): 19-28.

MaI D. H. 1995. - Tertiäre Vegetationsgeschichte Europas - Methoden und Ergebnisse. G. Fischer, Jena.

MartinetTo E. 1999. - Chronological framing of Pliocene to Early Pleistocene plant macrofossil assemblages from northern Italy. Acta Palaeobotanica 2: 503-511.

Medus J. 1965. — L'évolution biostratigraphique d'une lagune néogène de Galice (Espagne). Pollen et Spores VII (2): 381-393

Meller B., Kovar-Eder J. \& ZetTer R. 1999. - Lower Miocene leaf, palynomorph and diaspore assemblages from the base of the lignite-bearing sequence in the opencast mine Oberdorf, N Voitsberg (Styria, Austria) as an indication of "Younger Mastixioid" vegetation. Palaeontographica Abteilung B, 252: 123-179.

NonN H. 1966. - Les régions côtières de la Galice (Espagne), étude géomorphologique. Faculté des Lettres de l'Université de Strasbourg, $591 \mathrm{p}$.

NonN H. 1967. — Les terrasses du Rio Miño inférieur. Localisation et étude sédimentologique. Revue de Géomorphologie Dynamique XVII (3).

Pais J., Gregor H. \& Pereira D. (non published). Fossil Plants from Barrocas (S. Pedro da Torre), North
Portugal.

Pereira D. 1989. - Sedimentologia e estratigrafia dos depósitos quaternários do rio Minho (região de S. Pedro da Torre). Provas A.P.C.C., Universidade do Minho, $132 \mathrm{p}$.

Pereira D. 1991. - Evolução quaternária do rio Minho na região entre S. Pedro da Torre e Valença. Memórias Notas e Publicaçóes do Museu Laboratório Mineralógico Geológico (Universidade do Coimbra), 112 (B): 327-347.

POÇAS E. 2004. - Contribuição da palinologia para a caracterização paleoecológica e paleoclimática do Cenozóico a norte do Douro. Dissertação de Mestrado, Departamento de Ciências da Terra, Universidade do Minho, 116 p.

SANTANACH P. 1994. - Las Cuencas Terciarias gallegas en la terminación occidental de los relieves pirenaicos. Cuadernos do Laboratorio Xeolóxico de Laxe 19: 57-71.

ŠEvcík J., KVACEK Z. \& Mai D. H. 2007. - A new mastixioid florula from tektite-bearing deposits in South Bohemia, Czech Republic (Middle Miocene, Vrábče Member). Bulletin of Geosciences 82 (4), Czech Geological Survey: 429-436.

Solé De Porta N. \& Valle M. F. 1986. - Estudio palinológico del Plioceno de San Onofre (Tarragona). Estudios Geológicos 42: 63-66.

Solomon A. M. 1983a. - Pollen morphology and plant taxonomy of red oaks in eastern North America. American Journal of Botany 70: 495-507.

Solomon A. M. 1983b. — Pollen morphology and plant taxonomy of white oaks in eastern North America. American Journal of Botany 70: 481-494.

SuC J.-P. \& CRAVATtE J. 1982. — Étude palynologique du Pliocène de Catalogne (nord-est de l'Espagne). Paléobiologie Continentale 13: 1-31.

Suc J.-P., Diniz F., Leroy S., Poumot C., Bertini A., Clet M., Bessais E. \& Ferrier J. 1995a. —Zanclean $(\sim$ Brussumian) to early Piacenzian ( - early-middle Reuverian) climate from $4^{\circ}$ to $54^{\circ}$ north latitude (West Africa, West Europe and West Mediterranean). Mededelingen Rijks Geologish Dienst, Netherlands, 52: 43-56.

Suc J.-P., Bertini A., Comborieu-Nebout N., Diniz F., Leroy S., Russo-Ermolli, E., Zheng Z., Bessais E. \& Ferrier J. 1995b. - Structure of West Mediterranean vegetation and climate since 5,3 ma. Acta zoologica Cracoviense 38: 3-16.

Suc J.-P., Fauquette S., Bessedik M., Bertini A., Zheng Z., Clauzon G., Suballyova D., Diniz F., Quezel P., Feddi N., Clet M., Bessais E., Bachiri Taoufiq N., Méon H. \& Combourieu-Nebout N. 1999. - Neogene vegetation changes in West European and West circum-Mediterranean areas, in Agustí J., Rook L. \& ANDrews P. (eds), Hominoid Evolution and Climatic change in Europe. Cambridge University Press, Cambridge 1: 378-388. 
Teixeira C. 1944. - Tectónica Plio-pleistocénica do noroeste peninsular. Boletim da Sociedade Geológica de Portugal IV (I-II): 19-40.

VAN CAMPO E. 1979. - Flore pollinique et climat pliocènes au lac Ichkeul (Tunisie). Ecole pratique des Hautes Études, Mémoires et travaux de l'Institut de Montpellier, $42 \mathrm{p}$.

Vieira M. 2009. - Palinologia do Pliocénico da Orla Ocidental Norte e Centro de Portugal: Contributo para a compreensão da cronostratigrafia e da evolução paleoambiental. Ph.D. thesis, Universidade do Minho, Braga, Portugal, $389 \mathrm{p}$.

Vieira M., Zetter R., Castro L., Pais J. \& Pereira D.
2009. - Método combinado de observaçáo em microscópia óptica e electrónica de varrimento para estudo de palinomorfos (Combinated LM-SEM method for palynomorphs study). Comunicaçôes do Instituto Geológico e Mineiro, Tomo 96: 123-128.

WANG C. W. 1961. - The Forest of China (with a Survey of Grassland and Desert Vegetation). Maria Moors Cabot Foundation, Harvard University, Harvard, 313 p.

ZetTeR R. 1989. - Methodik und Bedeutung einer routinemäßig kombinierten lichtmikroskopischen und rasterelektronenmikroskopischen Untersuchung fossiler Mikrofloren. Courier Forschungsinstitut Senckenberg, 109: 41-50.

Submitted on 2 February 2010; accepted on 11 January 2011. 